\title{
Literatura dla dzieci - więcej pytań niż odpowiedzi
}

\section{Children's Literature: More Questions than Answers}

\author{
|Anna Czabanowska-Wróbel \\ Uniwersytet Jagielloński
}

\begin{abstract}
The aim of this article is to pose questions concerning the contemporary situation of children's literature. The growing significance of books for children in the 21st century should be regarded with optimism. However, the interesting phenomena on the book market do not necessarily directly transfer into positive and long-lasting changes in the reading habits of children and teenagers.

Key words: children's literature, sociology of literature, reading habits of children and teenagers in Poland

Streszczenie: Celem artykułu jest postawienie pytań dotyczących współczesnej sytuacji literatury dziecięcej. Rosnące znaczenie książki dziecięcej w XXI wieku powinno budzić optymizm. Jednak ciekawe zjawiska na rynku książki niekoniecznie przekładają się w sposób bezpośredni na trwałe i pozytywne zmiany w dziedzinie czytelnictwa dzieci i młodzieży.
\end{abstract}

Słowa kluczowe: literatura dziecięca, socjologia literatury, czytelnictwo dzieci i młodzieży w Polsce

Książka dziecięca w XXI wieku ma się w Polsce dobrze. Czytelnictwo dzieci i młodzieży - już niekoniecznie. To nie jedyny paradoks obecnej sytuacji wnikliwie diagnozowanej przez specjalistów z różnych dziedzin, co nie znaczy w pełni rozpoznanej jako skomplikowane, wieloimienne zjawisko.

Czasami warto się zatrzymać i podjąć refleksję na najbardziej podstawowe tematy. Samo postawienie pytań bywa przy tym cenniejsze niż podanie gotowych wniosków; właśnie dlatego w trybie ogólnej refleksji i wątpliwości raczej niż konkluzji chcę dodać coś do konkretnych uwag specjalistów.

Pierwsze z ogólnych pytań brzmi: Jakie są granice pola, w którym przyszło działać nam samym? Jakie są nasze możliwości działania, jak to się przekłada na rzeczywiste efekty? Posługuję się tu kategorią pola w sensie, 
w jakim zdefiniował ją Pierre Bourdieu. Odwołując się do myśli dwudziestowiecznego francuskiego socjologa, powtórzę za nim:

kiedy jest się świadomym tego, co się robi i co się dzieje w rzeczywistości, z której się jakiś fragment wyabstrahowało, można przynajmniej nakreślić główne linie funkcjonowania w przestrzeni różnych sił, które wywierają nacisk na punkt przez nas rozważany. (...) A przede wszystkim wówczas nie ryzykuje się poszukiwań (i „znalezienia”) w badanym fragmencie mechanizmów i zasad, które w rzeczywistości znajdują się na zewnątrz niego, w jego relacjach z innymi przedmiotami (Bourdieu 2001, 231-232).

Przechodząc z poziomu tej metarefleksji do konkretów, trzeba pogodzić się z sytuacją, w której wpływ naszych wskazówek i postulatów na zmieniającą się rzeczywistość społeczną nie jest wielki. Dodajmy, sytuację, w której oczekiwania i wyobrażenia rozmaitych grup: wydawców, bibliotekarzy, nauczycieli, rodziców, wreszcie badaczy nieuchronnie różnią się od siebie. Czasami mamy też do czynienia (czego również nie należy ignorować) z jawnym lub ukrytym konfliktem interesów.

Zauważmy przy tym nieco bardziej optymistycznie, że nasze wspólne pytanie brzmi „Co będą czytać dzieci?” Nie trzeba bowiem powtarzać pytania zadawanego często na przełomie XX i XXI wieku: „czy będą czytać?”, bo w gronie, które prowadzi rozmowę o „książce, która jest światem” (by przywołać celny tytuł Alicji Baluch), ta wątpliwość i ta obawa bardzo się oddaliły. Nowe techniki, nowe media nie usunęły tradycyjnej książki w cień. A wielki powrót pięknie wydawanych, ilustrowanych przez wybitnych artystów książek dziecięcych może tylko cieszyć.

Dodajmy jeszcze, że pozycja kogoś, kto zajmuje się literaturą dziecięcą, w ostatnich latach stanowczo się umocniła, gdyż sama literatura dziecięca zyskuje na znaczeniu. W obecnym stuleciu $\mathrm{z}$ dużym powodzeniem rozwijają się zarówno w Polsce, jak i w świecie rozmaite odmiany badań nad literaturą dziecięcą i młodzieżową, w tym także bliskie mi badania kulturowe nad samym dzieciństwem. Dowodem tego ożywienia zainteresowań badawczych są między innymi spotkania i konferencje, których plonem są interesujące i inspirujące książki wydawane w różnych ośrodkach akademickich, napisane tak, że z pożytkiem mogą je czytać niespecjaliści.

Literaturoznawca występuje dziś $w$ poszczególnych, nie zawsze rozszczepionych rolach - historyka literatury, korzystającego swobodnie z warsztatu nowoczesnego kulturoznawstwa, krytyka literackiego, wskazującego wartościowe nowości, zajmującego się czytelnictwem eksperta, wreszcie - w dalszym ciągu w szczęśliwej roli czytelnika amatora, znajdującego radość i przyjemność lektury. Pomiędzy tymi rolami występują jednak napięcia i konflikty, nie zawsze uświadamiane przez odbiorców tekstów, które trafiają do nich w różnych obiegach. Najtrudniejsze do pogodzenia wydają się role badacza i eksperta z zadaniem krytyka i recenzenta. W ich ramach różni się zwłaszcza perspektywa oglądu, z której opisuje się dane zjawisko. Największy dystans występuje (i jest konieczny) w przypadku badacza, najmniejszy i najkrótszy dystans, także czasowy, dotyczy 
recenzenta. Wspólna jest wszystkim rolom odpowiedzialność za słowa i wymóg niekomercyjnego charakteru opinii (najistotniejsza w przypadku etyki eksperta, najsłabiej zaznaczająca się u recenzenta). I kolejna kwestia - sprawa sądów wartościujących, najważniejsza dla krytyka, nie tak istotna, jak można sądzić, w spojrzeniu badacza, którego mogą zainteresować zarówno utwory wysokoartystyczne, poddawane interpretacji literaturoznawczej, jak i zjawiska symptomatyczne, mówiące coś istotnego o kulturze, która je stworzyła.

Książkami dziecięcymi wydawanymi w Polsce w ostatnich kilkunastu latach i źródłami informacji na ich temat trzeba zainteresować przede wszystkim młodych ludzi, którzy prawdopodobnie będą mieli z nimi wkrótce do czynienia jako rodzice, ale zwłaszcza kształcących się dziś przyszłych nauczycieli, bibliotekarzy, edytorów, po to, by nie zasklepiali się w poznanych we wczesnych latach lekturach, by umieli sami odkrywać cenne nowości i rozpoznawać rzeczy godne uwagi. Gdy zdarza mi się słyszeć, jak studenci polonistyki, dzisiejsi dwudziestoparoletni, wśród książek dla dzieci wymieniają nadal uparcie utwory napisane kilkadziesiąt lat temu, w czasach, kiedy ich samych nie było jeszcze na świecie, nie jestem najszczęśliwsza, ale nie protestuję. Żałuję, że skądinąd zacne książki, takie jak $O$ psie, który jeździł koleja czy Oto jest Kasia są tym, co dzisiejszy młody człowiek zapamiętał i bezrefleksyjnie chce przekazywać dalej dzieciom urodzonym już w nowym stuleciu. Inercyjne reprodukowanie w nieskończoność tych samych tekstów (w istocie nienależących do jakiegokolwiek kanonu) nie zastąpi odwiedzin w księgarni i bibliotece dziecięcej. Nie jest dobrze, gdy zamiast autentycznej ciekawości i poszukiwania tego, co nowe i atrakcyjne, pojawia się nuda i rutyna. W najnowszej książce poświęconej aktualnym problemom czytelnictwa dzieci i młodzieży Grzegorz Leszczyński wypowiada się o tym z retoryczną swadą:

z powodu każdej nudnej książki w księgozbiorze, słabej, nijakiej, letniej, z każdej książki ugrzecznionej i wolnej od czytelniczych emocji każdy - czy to rodzic, czy bibliotekarz, czy nauczyciel, czy babcia lub dziadek, ciocia lub wujek, czy wydawca, czy księgarz - po prostu każdy powinien odbywać srogie pokuty. Najlżejsza kara to dziesięć lat nudnych lektur. Bez taryfy ulgowej (Leszczyński 2015, 12).

Nie jest to jeszcze problem najcięższego kalibru, w przeciwieństwie do zagrożenia kiczem i tandetą, o którym tak pisze Leszczyński:

Powodów, dla których publikuje się mnóstwo tandety, jest wiele. Jednym z nich jest infantylizowanie dzieci - dorosłym bardzo często się wydaje, że im więcej lukru, różu, brokatu i połysku, tym książka bardziej spodoba się dziecku. (...) To my, dorośli, infantylizujemy dzieciństwo, wtłaczamy je w gorset własnych zdziecinniałych, naiwnych wspomnień ukutych na miare jednostkowych mitologii i społecznych wyobrażeń o rzekomej sielance dzieciństwa, a następnie stajemy na straży tego, by wyobrażeń tych i mitów nic nie naruszyło. (...) Tęsknota za tym, co minione, splata się z niedojrzałością w ocenie doświadczeń dziecka, jego przeżyć, stanów emocjonalnych i cierpień. Stąd właśnie popyt na kicz, tandetę i śmieciowe żarcie 
książkowe. Książki dojrzałe kierowane są do dzieci za pośrednictwem dojrzałych rodziców, nauczycieli i bibliotekarzy; książki niedojrzałe przeciwnie - znajdują uznanie w rękach niedojrzałych dorosłych (Leszczyński 2015, 12-13).

Opisana tu sugestywnie sytuacja pozwala mi zauważyć, że książki wręczają dzieciom nie tylko konkretni dorośli, ale całe instytucje i grupy społeczne. Nigdy nie dość podkreślać, że mamy do czynienia ze zjawiskiem ogromnego zróżnicowania społecznego, które jest związane z sytuacją wyboru książek, dostępu do nich i do samej lektury. Widzieliśmy z pewnością nieraz „śmieciowe” książeczki wysypujące się z koszy w wielkich supermarketach, produkty, udające książki i uspokajające opiekunów, i to w dodatku tych, którzy chcą dla dzieci tego, co najlepsze, takich, którzy już wiedzą, że lektura jest potrzebna, ale którzy jeszcze nie potrafią jej sami dobrze wybrać.

Natomiast w kręgu elitarnym (co na szczęście nie znaczy, że w Polsce bardzo wąskim) dzieci razem z nie mniej rozentuzjazmowanymi opiekunami biorą udział $\mathrm{w}$ festiwalach literackich i spotkaniach $\mathrm{z}$ pisarzami, buszują z rodzicami na targach książki, trafiają pod opieką dziadków do muzeów literackich i do małych księgarni, idą z rodzeństwem na anonsowane w prasie i internecie (ale dla wielu „niewidzialne”, mimo że bezpłatne) spotkania do coraz nowocześniejszych i coraz bardziej atrakcyjnych bibliotek.

$\mathrm{Na}$ trochę tylko wyjaskrawionym przykładzie przedstawię obecną sytuację w sposób nieco ukonkretniony. Kilkuletniej dziewczynce „niewidzialna ręka rynku" podaje jedną z wielu anonimowych, powielanych na całym świecie książeczek o księżniczkach (nie są to w istocie nawet książki, ale produkty książkopodobne), „wychowując” - nie, nie czytelniczkę, przede wszystkim przyszłą konsumentkę, uzależnioną od kupowania rozmaitych, mających dać jej szczęście gadżetów. W tym czasie inna mała dziewczynka dostanie $\mathrm{w}$ rodzinnym domu - wcale nie arcydzieło, ale po prostu jedną z wielu prawdziwych, współcześnie stworzonych w Polsce adresowanych do niej książek: bezpretensjonalną opowieść Roksany Jędrzejewskiej-Wróbel o królewnie Aurelce, zilustrowaną przyjaźnie przez Jonę Jung, utwór Marii Ewy Letki Królewna $w$ koronie z doskonałymi ilustracjami Marii Ekier albo przekornie napisaną nowość z 2015 roku, której autorem jest Grzegorz Kasdepke, zatytułowaną A ja nie chcę być księżniczka, opracowaną graficznie przez ilustratorkę najmłodszego pokolenia, Emilię Dziubak. Czy to właśnie te ostatnie książki zapewnią przyszły sukces szkolny małej czytelniczce, sukces, który można z łatwością przepowiedzieć, czy to raczej sytuacja rodzinna i społeczna owej dziewczynki skazuje ją wręcz na dobrą pozycję w hierarchii społecznej? Mój przykład - „bezparytetowo” - dotyczył czytelniczki, ponieważ we wszystkich statystykach zaznacza się ta właśnie różnica: w Polsce małe dziewczynki, nastolatki i dorosłe kobiety czytają więcej, chłopcy i dorośli mężczyźni - mniej, przy czym czytają głównie ci chłopcy, którzy widują ojca z książką i którym to ojciec daje coś 
do czytania (i niekoniecznie chodzi tu o beletrystykę, częściej o literaturę popularnonaukową z różnych dziedzin).

Na koniec czas na postulaty, z których ogólnego charakteru już się po trosze wytłumaczyłam, akcentując moją rolę dążącego do naukowej autonomii badacza bardziej niż recenzenta.

Istotne jest, aby dziecięcy księgozbiór w XXI wieku cechowała różnorodność, tak by znalazły się w nim utwory polskie i tłumaczone $\mathrm{z}$ kilku języków światowych (nie tylko z angielskiego, który, jak to wynika z badań, zdominował rynek, listy bestsellerów i książek wybieranych samodzielnie przez młodych czytelników). Konieczne jest wyjaśnienie wszystkim, którzy mają bezpośredni wpływ na to, co czytają dzieci, że napisanej współcześnie po polsku książki nie mogą całkowicie zastąpić nawet najbardziej interesujące dzieła światowe i to w najlepszych tłumaczeniach. Powody są co najmniej dwa. Pierwszy wiąże się z najbliższą rzeczywistością i z przestrzenią kulturową, z którą dzieci mają do czynienia. To jej literacki obraz (realistyczny lub metaforyczny) jest im potrzebny. Drugi powód związany jest z językiem. Pisane po polsku książki współtworzą obraz świata, pomagają ustanawiać w języku dziecięcego odbiorcy umiejętność adekwatnego, bogatego i plastycznego, a przy tym - właśnie przez język - zakorzenionego w naturalny sposób w przeszłości, wyrażania zarówno refleksji, jak i emocji.

Wśród dziecięcych lektur powinny się znaleźć książki współczesne i dawne, ze znaczną przewagą współczesnych. Gdy chodzi o pozycje dawniejsze, istotne jest kryterium ich obiektywnej, nieprzemijającej wartości, książki nowsze nie muszą być arcydziełami, wystarczy, by były „wystarczająco dobre”, jak „wystarczająco dobrzy rodzice”. Powinny być wśród nich takie, które pozwolą na wspólną rozmowę z najbliższymi i kontakt z najstarszym pokoleniem. Ale i takie, które można czytać w samotności, gdy się już tę umiejętność opanuje.

W mojej opinii książki dla najmłodszych dzieci nie mogą wchodzić w konflikt ze światopoglądem opiekunów, nie powinny w żaden sposób ranić najbliższych dziecku dorosłych, obrażając ich samych, ich uczucia i zmysł estetyczny; postulat ten rozumiem oczywiście bardzo szeroko, gdyż dla jednych rodzin nie do przyjęcia będzie narzucanie czegoś, co potraktują jako zbyt nowoczesne, dla innych - nazbyt konserwatywne. Opiekunowie mają bardzo krótko, bo jedynie przez pierwsze lata życia dziecka, przywilej, z którego zgodnie ze swoją najlepszą wiedzą o małym dziecku i jego etapie rozwojowym mogą skorzystać, by świadomie dobierać jego lektury, tak by nie wprowadzać zbędnego, niepokojącego dysonansu do jego świata. Natomiast w przypadku starszych dzieci jest inaczej - konieczne są właśnie takie książki, które otwierają oczy na to, że poza kręgiem najbliższej rodziny istnieją rozmaite poglądy na świat, inni, niepodobni do nas ludzie, a nawet zupełnie inne światy...

Warto, by nadal istniały książki, które będą wspólne dla całych roczników, które będą naznaczały kolejne generacje „dziecięcym przeżyciem 
pokoleniowym", książki, z których cytatami będzie się można porozumiewać i bawić. Ale nic nie przeszkadza temu, by były też książki jedynie dla niektórych, wydawane w małych nakładach, spełniające ściśle zdefiniowane, konkretne potrzeby emocjonalne i edukacyjne. Wreszcie - książki wysokoartystyczne, „dziwne”, całkowicie niekomercyjne, nienastawione na masowego dziecięcego odbiorcę, trafiające wprost do „nielicznych szczęśliwców”.

Trzeba się tylko cieszyć, że pojawia się ostatnio taka różnorodność wśród nowości książkowych, z których my dorośli możemy wybierać, a czytające samodzielnie dzieci mogą budować swoje prywatne światy wyobraźni. Dobrze, by wciąż istniały i powstawały takie książki, które pozostają w dzieciństwie, by można je było potem z nostalgią wspominać i takie, które rosną i zmieniają się razem z dzieckiem...

\section{Bibliografia:}

Baluch Alicja, 2005, Ksiqżka jest światem. O literaturze dla dzieci małych oraz dzieci starszych i nastolatków, Kraków.

Baluch Alicja, 2003, Od ludus do agora. Rozważania o ksiażkach dla młodzieży i o sposobach lektury, które wioda od zabawy do poważnej rozmowy o literaturze, Kraków.

Bourdieu Pierre oraz Wacquant Loïc J. D., 2001, Zaproszenie do socjologii refleksyjnej, Sawisz A. (przeł.), Warszawa.

Leszczyński Grzegorz, 2007, Magiczna biblioteka. Zbójeckie księgi młodego wieku, Warszawa.

Leszczyński Grzegorz, 2015, Wielkie małe książki. Lektury dzieci. I nie tylko, Poznań.

Papuzińska Joanna, 2007, Dziecięce spotkania z literatura, Warszawa.

Zabawa Krystyna, 2013, Rozpoczęta opowieść. Polska literatura dziecięca po 1989 roku wobec kultury współczesnej, Kraków.

\section{O Autorce:}

Anna Czabanowska-Wróbel, prof. dr hab., pracuje na Wydziale Polonistyki Uniwersytetu Jagiellońskiego, kieruje Ośrodkiem Badań Literatury Dziecięcej i Młodzieżowej WP UJ, zajmuje się badaniami nad literaturą Młodej Polski, poezją współczesną i tematem dziecka w literaturze. Autorka książek Baśń w literaturze Młodej Polski (1996), Dziecko. Symbol i zagadnienie antropologiczne w literaturze Młodej Polski (2003). 